Olekshij P. V. Characteristics of cytokine status in the pathogenesis of experimental periodontitis and immobilization stress. Journal of Education, Health and Sport. 2021;11(08):504-509. eISSN 2391-8306. DOI http://dx.doi.org/10.12775/JEHS.2021.11.08.056 https://apcz.umk.pl/JEHS/article/view/JEHS.2021.11.08.056

https://zenodo.org/record/5579592

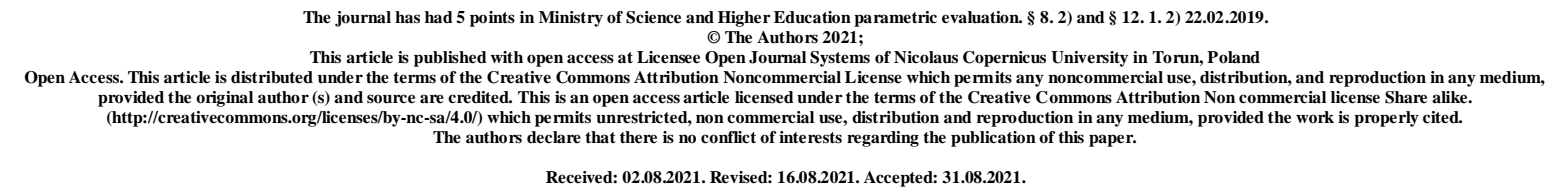

UDC: 616.314.18-002.4-092:612.176:616.155.3-097.37]-092.9

\title{
Characteristics of cytokine status in the pathogenesis of experimental periodontitis and
} immobilization stress

\section{P. V. Olekshij}

\section{Lviv Medical Institute}

\begin{abstract}
The aim of our study is to elucidate changes in the content of pro-inflammatory interleukin-6 (IL-6) and tumor necrosis factor- $\alpha$ (TNF- $\alpha$ ) and anti-inflammatory cytokines interleukin-10 (IL-10) in the blood serum of guinea pigs in the dynamics of experimental periodontitis and immobilization stress.

The dynamics of the combined pathology (experimental periodontitis and immobilization stress) is accompanied by a pronounced progression of the proinflammatory group of cytokines - TNF- $\alpha$ and IL-6 against the background of declining functional activity of IL-10 at all stages of their formation $\left(3^{\text {rd }}, 5^{\text {th }}\right.$ and $15^{\text {th }}$ days) with an advantage on the $15^{\text {th }}$ day of the experiment. The data obtained indicate an imbalance of pro- and anti-inflammatory cytokines and impaired cytokinogenesis, which is important for the pathogenesis in this combined pathology.
\end{abstract}

Key words: periodontitis; stress; cytokines. 


\title{
Характеристика цитокінового статусу в патогенезі розвитку експериментального пародонтиту та іммобілізаційного стресу
}

\author{
П. В. Олекшій
}

\section{Львівський медичний інститут}

Метою нашого дослідження є 3'ясування змін вмісту рівня прозапальних інтерлейкіну-6 (ІЛ-6) і фактору некрозу пухлин- $\alpha$ (ФНП- $\alpha$ ) та протизапальних цитокінів інтерлейкіну-10 (ІЛ-10) у сироватці крові морських свинок у динаміці розвитку експериментального пародонтиту та іммобілізаційного стресу.

Динаміка розвитку поєднаної патології (експериментального пародонтиту та іммобілізаційного стресу) супроводжує виражену прогресію прозапальної групи цитокінів - ФНП- $\alpha$ та IL-6 на тлі спаду функціональної активності IL-10 на усіх етапах їх формування (3-я, 5-a та 15-а доби) з перевагою на 15-у добу експерименту. Одержані дані свідчать про розбалансування про- і протизапальних цитокінів та порушення цитокіногенезу при даній поєднаній патології.

Ключові слова: пародонтит; стрес; цитокіни.

Характеристика цитокинового статуса в патогенезе развития экспериментального пародонтита и иммобилизационного стресса

\section{П. В. Олекший}

\section{Львовский медицинский институт}

Целью нашего исследования является выяснение изменений содержания уровня провоспалительных интерлейкина-6 (ИЛ-6) и фактора некроза опухолей- $\alpha$ (ФНО- $\alpha$ ) и противовоспалительных цитокинов интерлейкина-10 (ИЛ-10) в сыворотке крови морских свинок в динамике развития экспериментального пародонтита и иммобилизационного стресса.

Динамика развития сочетанной патологии (экспериментального пародонтита и иммобилизационного стресса) сопровождает выраженную прогрессию 
провоспалительной группы цитокинов - ФНО- $\alpha$ и IL-6 на фоне спада функциональной активности IL-10 на всех этапах их формирования (3-е, 5-е и 15-е сутки) с преимуществом на 15-е сутки эксперимента. Полученные данные свидетельствуют о разбалансировке про- и противовоспалительных цитокинов и нарушение цитокиногенеза при данной совмещенной патологии.

\section{Ключевые слова: пародонтит, стресс, цитокины.}

Introduction. Cytokines $(\mathrm{CCs})$ are glycosylated polypeptides that regulate and determine the nature of the immune response [4]. In healthy individuals, CCs are produced in minimal quantities sufficient for the manifestation of the biological effect, in pathological conditions, their content increases many times over. Inducers of increased synthesis of CCs are infectious microorganisms, products of their activity, toxins, food, drugs, plant allergens, as well as altered, modified proteins, cells of the body [5]. In recent years, the question of the role of cytokine status disorders in the initiation and progression of the inflammatory process in periodontal disease has been actively discussed [6]. Of course, microorganisms play a direct role in the occurrence of periodontal disease. The pathogenic effect of the microflora is manifested when microorganisms either accumulate in very large quantities (reach the "critical mass"), and conventional defense mechanisms are unable to neutralize their toxic and enzymatic effects, or when the activity of local protections is insufficient [3]. Compromised immune system and cytokine secretion processes under the influence of various factors can change their properties and thus form the severity of the disease, as the immune system through a cascade of cytokines carries out the immune response $[4,6]$.

The aim of our research was to determine the character of the disturbances content level of pro-inflammatory tumor necrosis factor - $\alpha$ (TNF- $\alpha$ ), interleukin-6 (IL-6) and antiinflammatory cytokine interleukin-10 (IL-10) in the serum of guinea pigs in the conditions of combined pathology formation - experimental periodontitis (EP) and immobilization stress (IS).

Material and methods of research. Experimental studies were performed on 40 guinea pigs (males), weighing $0.18-0.21 \mathrm{~kg}$, kept on the standard diet of the vivarium of Danylo Halytsky Lviv National Medical University. Guinea pigs were divided into four groups (10 in each): the first - intact animals - control; the second (experimental) group animals with experimental periodontitis and immobilization stress ( $3{ }^{\text {rd }}$ day), the third group 
included guinea pigs with EP and IS on the $5^{\text {th }}$ day of the combined model process, to IV animals with EP and IS on the $15^{\text {th }}$ day.

Experimental periodontitis was modeled by the method of ZR Jogan (1983) [2]. Immobilization stress was reproduced by the method of PD Horizontov (1996) [1]. We selected fixed days $\left(3^{\text {rd }}, 5^{\text {th }}\right.$ and $15^{\text {th }}$ ) for studies that corresponded to the classic stages of acute inflammation. All experiments on laboratory animals carried out with following the European Convention for the protection of vertebrate animals used for experimental and other scientific purposes (Strasbourg, 1986), Council Directive 2010/63 / EU, the Law of Ukraine 3447- IV "protection animals from the cruelty," the general ethics of animal experimentation adopted by the first national Congress on bioethics in Ukraine (2001).

The IL-6, IL-10 and TNF- $\alpha$ concentration in the blood serum was defined for all groups of guinea-pigs. It was made using hard-phase immune-enzyme analysis (ELISA), by means of the test-system "Diaclone" (France). Numerical results were adapted with static method using Student's criteria.

Results of the study and their discussion. When studying the cytokine system in experimental periodontitis and immobilization stress, it was found that in all studied days of the experiment there were probable changes in the concentration of both pro-inflammatory and anti-inflammatory cytokines in comparison with the group of intact animals. During the study of pro-inflammatory CC IL-6 was found to increase its concentration by $63.3 \%$ $(\mathrm{p} \leq 0.05)$ on the $3^{\text {rd }}$ and $83.3 \%(\mathrm{p} \leq 0.05)$ on the $5^{\text {th }}$ day of the experiment compared with guinea pigs I group. Further, on the $15^{\text {th }}$ day of EP and IS, its growth was even more active by $100.0 \%(\mathrm{p} \leq 0.05)$ against the control group (Fig. 1).

A similar trend was observed for the next cytokine - TNF- $\alpha$, which is a typical proinflammatory cytokine and one of the markers of non-specific generalized inflammation. We note a gradual increase in this indicator depending on the duration of the pathological process: on the $3^{\text {rd }}, 5^{\text {th }}$ and $15^{\text {th }}$ days TNF- $\alpha$ increases by $71.0 \%(\mathrm{p} \leq 0.05), 84.2 \%(\mathrm{p} \leq 0.05)$ and $89.4 \%$ $(p \leq 0.05)$ respectively relative to control animals. Thus, the results of studies of the cytokine profile in the serum under the conditions of formation of EP and IS established an increase in the level of the pool of pro-inflammatory $\mathrm{CC}$, especially the most pronounced in animals of the fourth group (Fig. 1).

Analysis of the level of anti-inflammatory cytokine IL-10 on the $3^{\text {rd }}$ day of EP and IS showed a decrease of $44.9 \%(\mathrm{p} \leq 0.05)$ compared with the intact group. A further declining of IL-10 was recorded with the development of EP and IS. The decrease in this CC was 
observed on the $5^{\text {th }}$ day by $48.3 \%(\mathrm{p} \leq 0.05)$ and on the $15^{\text {th }}$ day by $55.0 \%(\mathrm{p} \leq 0.05)$ opposite the control (Fig. 1). The obtained data give grounds to assert the suppression of proinflammatory cytokines in the blood in the dynamics of EP and IS.

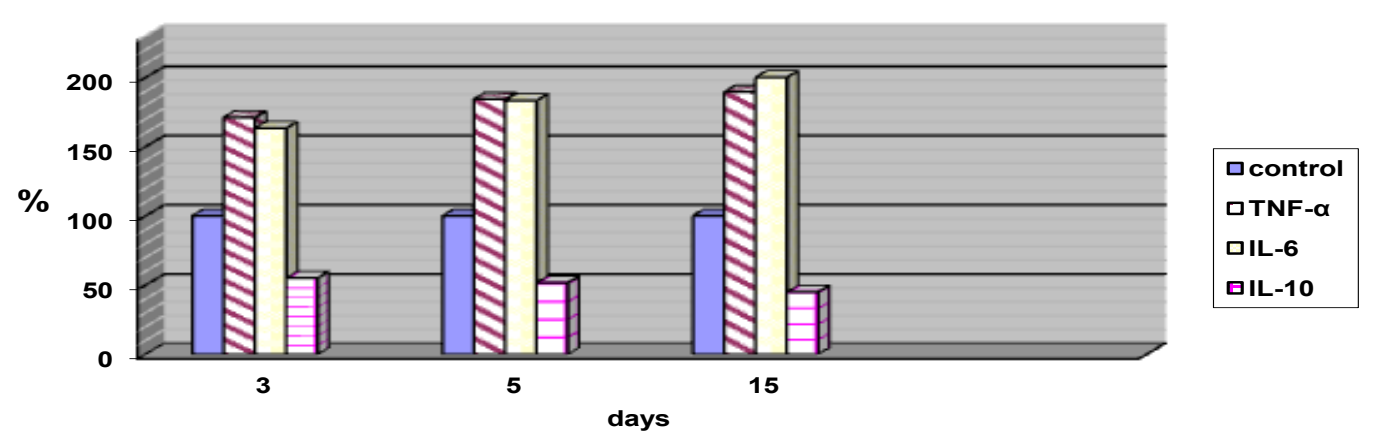

Fig.1. The level of TNF- $\alpha$, IL-6 and IL-10 in the blood in the dynamics of the formation of EP and IS (\% of control)

Thus, the study of cytokines (TNF- $\alpha$, IL-6 and IL-10) showed an increase in proinflammatory and a decrease in anti-inflammatory interleukins, which indicates an imbalance between pro- and anti-inflammatory CCs.

Conclusions. The dynamics of the combined pathology (experimental periodontitis and immobilization stress) is accompanied by a pronounced progression of the proinflammatory group of cytokines - TNF- $\alpha$ and IL-6 against the background of declining functional activity of IL-10 at all stages of their formation ( $3^{\text {rd }}, 5^{\text {th }}$ and $15^{\text {th }}$ days) with an advantage on the $15^{\text {th }}$ day of the experiment. The obtained data indicate an imbalance of proand anti-inflammatory cytokines and impaired cytokinogenesis, which is important for the pathogenesis of these diseases.

\section{References}

1. Gorizontov PD, Belousov OI, Fedotov MI (1983) Stress i systema krovi. M .: Medicine, p.338. (in Russian) 
2. Jogan ZR (1996) Clinico-experimentalne obosnovanie usovershenstvovania orthopedichnyx metodiv pry complexnomu likuvanni chvorob parodonta. Author's ref. Dis. Candidate of Medical Sciences, Kyiv, p.18. (in Ukrainian)

3. Kononova OV (2018). Eksperymentalne obhruntuvannia zastosuvannia adrenoblokatoriv. Sovremennaia stomatolohyia, 2: 86-89 (in Ukrainian).

4. Kolishetska MA (2021) Dynamika zmin cytokinovoho statusu u patohenezi rozvytku eksperymental'noyi bronkhial'noyi astmy ta vyrazkovoyi khvoroby shlunka. Visnyk mors'koyi medytsyny. №1 (90), Odessa, 64-68 (in Ukrainian)

5. Moudgil KD (2017) Interplay among cytokines and $\mathrm{T}$ cell subsets in the progression and control of immune-mediated diseases. Br J Biomed Sci, Jan;74(1):8-15.

6. Regeda-Furdychko MM (2020) Evaluation of the influence of thiotriazoline on the cytokine status disturbances in the blood serum under the condition of experimental contact dermatitis and experimental pneumonia. Journal of Education, Health and Sport. $10(1): 25-30$ 